\section{Cross-cultural adaptation of the Four Habits Coding Scheme (4HCS) for teaching and assessing patient-centered communication skills in Brazil}

\section{Adaptação transcultural do Four Habits Coding Scheme (4HCS) para o ensino e avaliação de habilidades de comunicação centradas no paciente no Brasil}

\section{Adaptación transcultural del Four Habits Coding Scheme (4HCS) para la enseñanza y evaluación de habilidades de comunicación centradas en el paciente en Brasil}

Renata Rodrigues Catani 1

Emiliana dos Santos Valadares 1

Julianni Bernardelli Lacombe 1

Tânia Maria da Silva Mendonça 1

Carlos Henrique Martins da Silva 1

Helena Borges Martins da Silva Paro 1

doi: $10.1590 / 0102-311 \times 00013918$
Correspondence

R. R. Catani

Faculdade de Medicina, Universidade Federal de Uberlândia. Av. Pará 1720, Bloco 2U, Sala 23, Uberlândia,

MG 38400-902, Brasil.

renata_rcatani@hotmail.com

1 Universidade Federal de Uberlândia, Uberlândia, Brasil. 


\section{Introduction}

In recent years, studies have reinforced patient-centered communication as one of the main reasons for reaching success, satisfaction and positive impacts on health care 1,2,3,4. In response to these results, several medical education guidelines $5,6,7,8,9$ point to the need of formalizing the teaching and the assessment of patient-centered care (PCC) communication skills ${ }^{10}$. Despite Brazilian guidelines reinforcing communication skills as an important competence for medical students ${ }^{9}$, formal communication skills training is less frequently reported among Brazilian medical schools in comparison to schools in the United States of America and United Kingdom 11. The scarce literature among Brazilian medical schools 12,13,14,15 also signalizes difficulties in implementing formal communication skills teaching in the country. The absence of validated tools for teaching and assessing communication skills in Brazil may be one of the contributing factors for this reality.

In the international context, several PCC-based tools have been developed to teach and assess communication skills in clinical practice 16,17. In comparison to the SEGUE-Framework 16 and the Calgary-Cambridge Guide 18, the Four Habits Coding Scheme (4HCS) is a shorter tool, with 5-point Likert scale items that distinguish students and health professionals into five different levels of performance (behavior categories), rather than into dichotomous behaviors (satisfactory/unsatisfactory or yes/ no). In the 4HCS, behaviors are coded according to categories defined under a conceptual model 19. Besides, the 4HCS was originally designed for use among health professionals and students, not only physicians and medical students.

The 4HCS is a user-friendly instrument that requires no technology nor faculty development programs for use. It is a low-cost tool that organizes the teaching of communication skills and assesses both medical students and health professionals in real life situations on a formative and summative basis. It is a relatively new instrument that has been validated only in English 19 (with tests of internal consistency, inter-rater reliability and criterion validity) and German 20 (with tests of internal consistency, inter-rater reliability, construct and criterion validity).

A Brazilian version equivalent to the original instrument may help boosting the communication skills teaching and research in Brazil as well as contribute to comparisons of communication skills outcomes among studies using the 4HCS in other countries. To this end, this study aims to translate and culturally adapt the 4HCS into Brazilian Portuguese.

\section{Methods}

This is a cross-cultural adaptation study, approved by the local research ethics committee, held after permission by E. Krupat, the author of the instrument. Students, residents and patients signed an informed consent form allowing recordings in the pretest stage.

\section{Instrument}

The 4HCS consists of 23 items rated on a 5-point Likert scale, with examinees being rated into 5 levels of performance (behavior categories). Higher scores indicate greater patient-centered communication skills 12. The items are divided into four domains that describe and measure medical behaviors based on previous experiences with the Four Habits Model 14. The Four Habits Model presents an organized way of thinking and acting in a clinical encounter in a PCC-based approach: (1) Invest in the beginning (6 items); (2) Elicit patient's perspective (3 items); (3) Demonstrate empathy (4 items); (4) Invest in the end (10 items).

\section{Procedure}

Cross-cultural adaptation was performed according to international guidelines 21,22 (Figure 1). In the first stage - forward translation - two bilingual translators native of Brazilian Portuguese produced two independent translations of the instrument from English into Brazilian Portuguese. In the second stage, a bilingual healthcare professional native of Brazilian Portuguese performed the reconciliation 
of the previous translations. In the third stage - back translation - an American translator fluent in Portuguese translated the reconciled version back into the original language. In the fourth stage, the author of the instrument made comments on the back translated version.

In the fifth stage, items, behavior categories, expressions, sentences or words identified as lacking semantic, idiomatic, experimental or conceptual equivalences in any stage of the translation process were sent to review. Five bilingual reviewers native of Brazilian Portuguese (two professional translators and three physicians with experience in the translation process of outcome measures) assessed all previous stages to choose the best translated option for the instrument. The modified Delphi technique 23,24 was used to reach consensus among reviewers in iterative electronic rounds organized by two research coordinators in semi-structured questionnaires on the Delphi Decision Aid website (http://armstrong.wharton.upenn.edu/delphi2/).

After each round, independent reviewers received feedback on the statistical analysis of responses. They also received suggestions made by other reviewers in each round. Questionnaires answered by the independent reviewers comprised the entire process of translation and were available to the reviewers during the entire process, which totaled four rounds. The process was completed after meeting at least $80 \%$ of consensus among participants 23,24 .

After adjustments made by the language coordinator (stage six), the instrument was sent to its author to produce the pre-final version. Three professors experienced in teaching communication skills, who did not participate in the previous stages, pretested the pre-final version (stage seven). They assessed four videos of real consultations provided by medical students and residents. After observing the videos, professors answered to a cognitive and retrospective interview aimed at assessing comprehension, applicability and relevance of items and behavior categories 25 . They also provided suggestions for improvement of the instrument 26 . The final Brazilian version of the $4 \mathrm{HCS}$ was produced after the pretest (Figure 1). See final version of the Brazilian 4HCS in the Supplementary Material (http://cadernos.ensp.fiocruz.br/csp/public_site/arquivo/suplementar_2178.pdf).

\section{Results}

The items that assess healthcare professionals' patient-centered behaviors during the clinical encounter required many rounds to achieve consensus in the Delphi technique. Only one item achieved consensus in the first round. To achieve the pre-final version, $62.5 \%$ of the items required at least three rounds. The items that posed the most difficulties were "Engage in small talk", "Expansion of concerns", "Elicit full agenda", "Use patient's frame of reference", and "Explore plan acceptability" (Table 1).

Some words in the category behavior were discrepant in the versions of the first three translation stages. Such discrepancies were solved either by applying the Delphi technique (Table 2) or by following the language coordinator's guidance (pre-final version). Consensus was reached in the first round in $80 \%$ of the words for which Delphi technique was necessary. The word "clinician", found in $91.3 \%$ of the category behavior, was translated and back translated as "physician". In the second round, even after been exposed to the dictionary definitions of the words "clinician", "physician", "clinico" and "médico", the independent reviewers' consensus was that its translation should remain as "physician" ("médico"). The language coordinator adjusted this word to "clinician" [healthcare professional], with the agreement of the author of the instrument, who stated that the target population of the 4HCS are health professionals, that is physicians, psychologists, nurses, or whoever is directly involved in patient care.

All participants in the pretest stage considered all items and behavior categories relevant and easy to understand. The three observers considered the instrument easy to use, although two of them pointed out that it takes long to complete the assessment. To solve this time issue, one of the observers suggested that the habits should be assessed separately. Another observer suggested that the item "Greet warmly" should be placed before the item "Show familiarity" in Habit 1. This suggestion was incorporated to the final version and aimed to facilitate the assessment by respecting the logical sequence of events in a clinical encounter (Supplementary Material: http://cadernos.ensp.fiocruz.br/ csp/public_site/arquivo/suplementar_2178.pdf). 


\section{Figura 1}

Translation and cultural adaptation of the Four Habits Coding Scheme (4HCS).

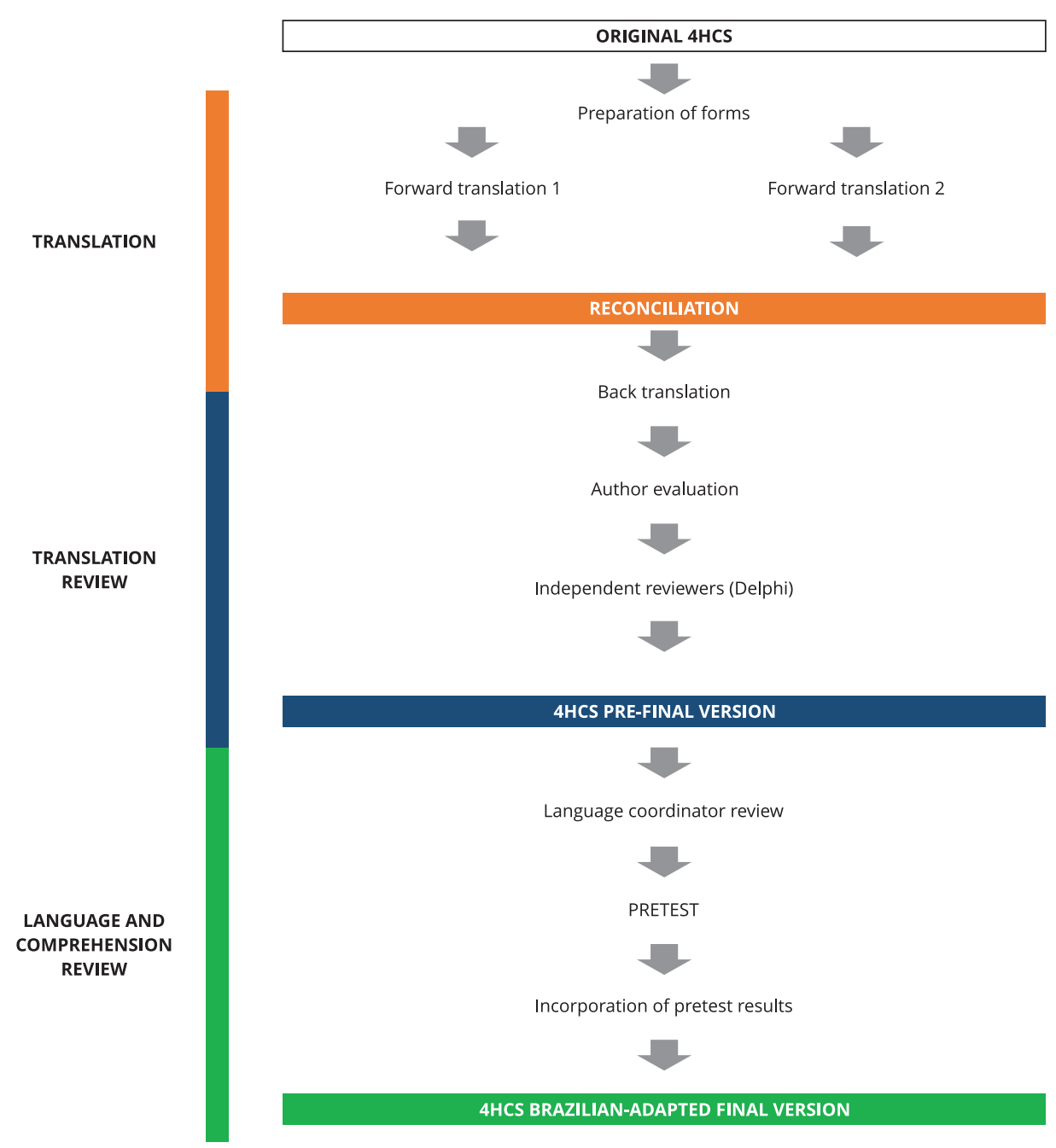

Fourteen items required adjustments after pretest to ensure better understanding among respondents and equivalence with the original version (Table 3). Among such changes, there is the inclusion of the meaning of the concept "staccato style" in one of the behavior categories of the item "Question style" of Habit 1.

\section{Discussion}

In Brazil, the PCC approach has been introduced in recent years, especially in the family practice scenario 3,27 . However, to the best of our knowledge, this is the first study carried out in Brazil that aims to translate and culturally adapt an instrument for teaching and assessing clinician's communication in real scenarios as a strategy to improve patient care. 
Table 1

Process to solve discrepant translations of items through Delphi technique.

\begin{tabular}{|c|c|c|c|c|}
\hline Original item & \multicolumn{2}{|r|}{ Translations } & \multirow{2}{*}{$\begin{array}{c}\text { Number of rounds } \\
\text { to reach consensus } \\
2\end{array}$} & \multirow{2}{*}{$\begin{array}{c}\begin{array}{c}\text { Percentage of } \\
\text { consensus }\end{array} \\
100\end{array}$} \\
\hline Show familiarity & T1 & Mostrar familiaridade & & \\
\hline & $\mathrm{T} 2$ & Demonstrar familiaridade & & \\
\hline & REC & Demonstrar familiaridade & & \\
\hline & BT & To demonstrate familiarity & & \\
\hline & Final & Demonstra familiaridade & & \\
\hline \multirow[t]{5}{*}{ Greet warmly } & $\mathrm{T} 1$ & Cumprimentar calorosamente & 2 & 100 \\
\hline & $\mathrm{T} 2$ & Cumprimentar afetuosamente & & \\
\hline & REC & Cumprimentar calorosamente & & \\
\hline & BT & A warm greeting & & \\
\hline & Final & Cumprimenta cordialmente & & \\
\hline \multirow[t]{5}{*}{ Engage in small talk } & $\mathrm{T} 1$ & Estabelecer diálogo & 3 & 80 \\
\hline & $\mathrm{T} 2$ & Estabelecer-se em uma conversa & & \\
\hline & REC & Envolver-se no diálogo & & \\
\hline & BT & Involvement in a dialogue & & \\
\hline & Final & Envolve-se em conversas sobre assuntos gerais & & \\
\hline \multirow{5}{*}{$\begin{array}{l}\text { Expansion of } \\
\text { concerns }\end{array}$} & $\mathrm{T} 1$ & Expansão das preocupações & 4 & 80 \\
\hline & $\mathrm{T} 2$ & Aumento das preocupações & & \\
\hline & REC & Obtendo as queixas & & \\
\hline & BT & Receiving complaints & & \\
\hline & Final & Aborda outras queixas (além da principal) & & \\
\hline \multirow[t]{5}{*}{ Elicit full agenda } & $\mathrm{T} 1$ & Obter cronograma completo & 3 & 80 \\
\hline & $\mathrm{T} 2$ & Obter agenda cheia & & \\
\hline & REC & Obter cronograma completo & & \\
\hline & BT & Obtaining the complete chronogram & & \\
\hline & Final & $\begin{array}{c}\text { Obtém a agenda completa (queixas, preocupações, } \\
\text { sentimentos e expectativas) }\end{array}$ & & \\
\hline \multirow{6}{*}{$\begin{array}{l}\text { Use patient's frame of } \\
\text { reference }\end{array}$} & T1 & Usar o quadro de referência do paciente & 3 & 80 \\
\hline & $\mathrm{T} 2$ & Quadro de referência de uso do paciente & & \\
\hline & REC & Utilizar o quadro do paciente como referência & & \\
\hline & BT & Use of the patient's file reference & & \\
\hline & Final & Utiliza as vivências e percepções do paciente como & & \\
\hline & & referência para o compartilhamento de informações & & \\
\hline \multirow{5}{*}{$\begin{array}{l}\text { Offer rationale for } \\
\text { tests }\end{array}$} & $\mathrm{T} 1$ & Oferecer lógica para os exames & 1 & 80 \\
\hline & $\mathrm{T} 2$ & Oferecer uma explicação para os testes & & \\
\hline & REC & Oferecer uma explicação para os exames & & \\
\hline & BT & Explanation of test results & & \\
\hline & Final & Oferece uma explicação para os exames & & \\
\hline \multirow{5}{*}{$\begin{array}{l}\text { Explore plan } \\
\text { acceptability }\end{array}$} & $\mathrm{T} 1$ & Explorar a aceitabilidade do plano & 3 & 100 \\
\hline & $\mathrm{T} 2$ & Explorar a aceitabilidade do método & & \\
\hline & REC & Oferecer uma explicação para os exames & & \\
\hline & BT & Acceptance of treatment & & \\
\hline & Final & Explora a aceitabilidade do plano terapêutico & & \\
\hline
\end{tabular}

BT: back translation; REC: reconciliation; T1: forward translation 1; T2: forward translation 2. 
Table 2

Process to solve discrepant translations of items in the category behavior through Delphi technique.

\begin{tabular}{|c|c|c|c|c|}
\hline \multirow{2}{*}{$\begin{array}{l}\text { Words } \\
\text { Clinician }\end{array}$} & \multicolumn{2}{|r|}{ Translations } & \multirow{2}{*}{$\begin{array}{c}\text { Number of rounds to reach } \\
\text { consensus }\end{array}$} & \multirow{2}{*}{$\begin{array}{c}\text { Percentage of consensus } \\
100\end{array}$} \\
\hline & $\mathrm{T} 1$ & Médico & & \\
\hline & $\mathrm{T} 2$ & Clínico & & \\
\hline & REC & Médico & & \\
\hline & BT & Physician & & \\
\hline & Final & Profissional de saúde & & \\
\hline \multirow[t]{5}{*}{ Chart } & $\mathrm{T} 1$ & Prontuário & 1 & 80 \\
\hline & $\mathrm{T} 2$ & Ficha & & \\
\hline & REC & Prontuário & & \\
\hline & BT & File & & \\
\hline & Final & Prontuário & & \\
\hline \multirow[t]{5}{*}{ Visits } & $\mathrm{T} 1$ & Visita & 1 & 100 \\
\hline & $\mathrm{T} 2$ & Consulta & & \\
\hline & REC & Visita & & \\
\hline & BT & Visits & & \\
\hline & Final & Consulta & & \\
\hline \multirow[t]{5}{*}{ Labeling } & $\mathrm{T} 1$ & Nomeação & 1 & 80 \\
\hline & $\mathrm{T} 2$ & Classificação & & \\
\hline & REC & Nomeação & & \\
\hline & BT & Speak of & & \\
\hline & Final & Nomeando & & \\
\hline \multirow[t]{5}{*}{ Cursory } & $\mathrm{T} 1$ & Superficial & 1 & 80 \\
\hline & $\mathrm{T} 2$ & Apressada & & \\
\hline & REC & Apressada & & \\
\hline & BT & Quickly & & \\
\hline & Final & Rápida/Superficial & & \\
\hline
\end{tabular}

BT: back translation; REC: reconciliation; T1: forward translation 1; T2: forward translation 2.

Although the national curriculum guidelines ${ }^{9}$ place good communication as one of medical students' core competences, no valid instrument is available to systematize the teaching of healthcare communication skills in Brazil. It is interesting to notice that Brazilian public health policies have been reinforcing the importance of communication in building one's autonomy and empowerment for over ten years 28,29 .

The time gap between the national curricular guidelines and the emergence of one of first instruments translated and adapted into Brazilian Portuguese reflects a complex reality in our country. Medical training often neglects the public health policies debate in Brazil 28. The divergence between public education and health policies derives from a disease-based model and a "complaint-action" orientation widespread in our society 28 . In this model, the physician usually has the knowledge and the power to decide upon both patient and staff; thus, the physician-patient relationship is often considered an "activity-passivity" or "guidance-cooperation" one 30. This type of relationship is usually asymmetrical and paternalist 31 .

This asymmetry in the physician-patient interaction is not exclusive to Brazil. Countries that have undergone curriculum reforms in medical education over forty years ago and have included scientific evidence-based strategies in communication skills training 32,33 have also faced difficulties in establishing less asymmetric relationships in healthcare 34 . The persistence of this phenomenon lays on dominance and power issues inherent to the social function of medical practice. Patients' deference to physician authority seems to be common in the asymmetric physician-patient relationship 34 . In a PCC approach, the necessary changes in health care and in physicians' attitudes and behavior 
Table 3

Pre-final version, pretest suggestions and final version of the Four Habits Coding Scheme (4HCS).

\begin{tabular}{|c|c|c|}
\hline Pre-final version & Pretest suggestions & Final item \\
\hline Brevemente; breve & Rapidamente; rápido & Rapidamente; rápido \\
\hline (...) (estilo staccato). & $\begin{array}{c}\text { (...) (estilo staccato - de forma rápida e com } \\
\text { interrupções bruscas). }\end{array}$ & $\begin{array}{c}\text { (...) (estilo staccato - de forma rápida e com } \\
\text { interrupções bruscas). }\end{array}$ \\
\hline $\begin{array}{l}\text { (...) (emite sinais verbais e não verbais de que } \\
\text { está tudo bem...) }\end{array}$ & $\begin{array}{c}\text { (...) (emite sinais verbais e não verbais } \\
\text { (contato visual, tom de voz, ...) de que está } \\
\text { tudo bem...) }\end{array}$ & $\begin{array}{c}\text { (...) (emite sinais verbais e não verbais de que } \\
\text { está tudo bem...) }\end{array}$ \\
\hline (...) dando a ele/ela pouca ou nenhuma & (...) dando a elelela pouca ou nenhuma & (...) dando a ele/ela pouca ou nenhuma \\
\hline explicação sobre eles. & explicação. & explicação sobre eles. \\
\hline (...) avalia brevemente ou de forma ineficaz & (...) avalia rapidamente, de forma ineficaz & (...) avalia rapidamente ou de forma ineficaz \\
\hline (...) claramente incentiva e convida o(a) & (...) incentiva claramente e convida o(a) & (...) incentiva claramente e convida o(a) \\
\hline paciente & paciente & paciente \\
\hline Explora a aceitabilidade do plano terapêutico & $\begin{array}{c}\text { Explora a concordância com o plano } \\
\text { terapêutico }\end{array}$ & Explora a aceitabilidade do plano terapêutico \\
\hline (...) implementação do plano terapêutico. & (...) adesão ao plano terapêutico. & (...) adesão ao plano terapêutico. \\
\hline $\begin{array}{l}\text { (...) faz planos facilmente compreensíveis e } \\
\text { específicos }\end{array}$ & (...) faz planos compreensíveis e específicos & (...) faz planos compreensíveis e específicos \\
\hline
\end{tabular}

engender psychological, political and sociological conflicts that certainly pose difficulties in such a paradigm shift. In addition to the difficulties in establishing a patient-centered communication, there seems to be remnants of a social structure and a relationship historically controlled by the physician and influenced by patriarchy and capitalism 35 .

This complex framework may have influenced the results of the translation stages of the 4HCS. The reality experienced by health professionals and translators seems to hamper consensus regarding expressions and words that refer to an active engagement of the patient and even to the physicianpatient partnership in a holistic approach to the person. In our study, medical specialists and translators had difficulty in reaching consensus on expressions that refer to the understanding the whole person, which one of the PCC core principles 3.

The translation of the word "clinician" is the most typical example of the difficulty in incorporating PCC principles into Brazilian medical practice. We believe that the difficulty in translating the word "clinician" and reaching consensus through the Delphi technique may be related to historical and political issues surrounding the medical profession. Even when provided with the definition of "clinician", both physicians and translators could not come to terms with it appropriately. In our opinion, the historically dominant physician behavior and the idea that the physician is the one responsible for establishing communication 34 may have influenced this result, eventually requiring the author's intervention. Difficulties in implementing PCC may be even higher in the context of clinical practice. Rhetoric-practice gaps have been identified among institutions that have embraced PCC in their overall mission, primarily due to difficulties in changing the "mindset" of health professionals 36.

Linguistics barriers in translation were also found. Upon author's approval, the language coordinator also modified the pre-final version of the instrument to meet grammatical and stylistic conventions in Brazilian Portuguese and to provide comprehension and terminological standardization. Such adjustments were necessary to overcome collocation inadequacies and literal translation, found in the pre-final version. Studies have reported the importance of cultural adaptation in the expressions used in the instruments. They have also suggested that culture inadequacies and imperfections in this stage of the translation process may lead to failures in the instruments' validation process 37,38 .

A pretest with retrospective and cognitive interviews targeted the respondents' comprehension of the translated items 22 and ensured that the translated instrument was both equivalent to the original and culturally adapted to Brazil. One example of adaptation is the introduction of an explanation for 
the term "staccato style", which had already been pointed out by the author of the instrument, as it may be an unknown expression among health care providers.

The use of rigorous translation and adaptation techniques with the participation of a group of qualified experts and language coordinators has resulted in a sound instrument. The Brazilian version of the 4HCS is an instrument that is culturally, conceptually, semantically and operationally equivalent to the original instrument 38 .

Our study has some limitations. Although the 4HCS has been designed for direct observation of students and health professionals without the requirement of technology, we used video recordings for pretesting the instrument. This approach may have influenced our results. Nevertheless, video recordings have also been used in previous adaptation and validation studies of the 4HCS 19,20. Also, we did not perform factor analysis of the $4 \mathrm{HCS}$. Therefore, we encourage future validation studies to test structural validity of the 4HCS and to evaluate the suggestion of assessing the habits separately, as time constrains may pose difficulties in implementing the 4HCS in educational and clinical practice.

\section{Conclusion}

The translation of the 4HCS resulted in an instrument adapted to the Brazilian culture, which can be used as an instrument for teaching and assessing communication skills in Brazilian medical schools. Future instrument validation studies should assess the psychometric properties of the items, especially of those that posed difficulty in the translation process. The Brazilian version of the 4HCS may represent an important advance for strengthening of the person-centered care model in Brazil.

\section{Contributors}

R. R. Catani and H. B. M. S. Paro contributed to the study design, data analysis and interpretation, and writing of the manuscript. E. S. Valadares contributed to the study design, data analysis and interpretation, and revision of manuscript. J. B. Lacombe contributed to data collection, data analysis, and revision of manuscript. T. M. S. Mendonça evaluated the data analysis and contributed to the writing of the article. C. H. M. Silva contributed to the study design, data analysis, and writing of the article.

\section{Acknowledgments}

The authors thank Lauryene Vilela and Prof. Edward Krupat for helping with the revision of the 4HCS. A special thanks to Alfredo Demétrio Jorge Neto for the important contributions on the pretest stage.

\section{References}

1. Pendleton D, editor. The consultation: an approach to learning and teaching. New York: Oxford University Press; 1984. (Oxford General Practice Series).

2. Stewart MA. What is a successful doctor-patient interview? A study of interactions and outcomes. Soc Sci Med 1984; 19:167-75.

3. Stewart M, editor. Patient-centered medicine: transforming the clinical method. 3rd Ed. London: Radcliffe Publishing; 2014.

4. Stewart M, Brown JB, Donner A, McWhinney IR, Oates J, Weston WW, et al. The impact of patient-centered care on outcomes. J Fam Pract 2000; 49:796-804.

5. Association of American Medical Colleges. Core entrustable professional activities for entering residency - curriculum developers' guide. Washington DC: Association of American Medical Colleges; 2014.

6. General Medical Council. Tomorrow's doctors. London: General Medical Council; 2009.

7. Royal College of Physicians. Doctors in society: medical professionalism in a changing world : report of a working party December 2005. London: Royal College of Physicians; 2005.

8. World Federation for Medical Education. WFME global standards for quality improvement. Copenhagen: WFME Office/University of Copenhagen; 2003.

9. Câmara de Educação Superior. Resolução no 3, de 20 de junho de 2014. Institui Diretrizes Curriculares Nacionais do Curso de Graduação em Medicina e dá outras providências. Diário Oficial da União 2014; 23 jun. 
10. Silverman J, Kurtz SM, Draper J. Skills for communicating with patients. 3 rd Ed. London: Radcliffe Publishing; 2013.

11. Liberali R, Novack D, Duke P, Grosseman S. Communication skills teaching in Brazilian medical schools: what lessons can be learned? Patient Educ Couns 2018; 101:1496-9.

12. Turini B, Martins Neto D, Tavares MS, Nunes SOV, Silva VLM, Thomson Z. Comunicação no ensino médico: estruturação, experiência e desafios em novos currículos médicos. Rev Bras Educ Méd 2008; 32:264-70.

13. Marco MAD, Vessoni AL, Capelo A, Dias CC. Laboratório de comunicação: ampliando as habilidades do estudante de medicina para a prática da entrevista. Interface Comun Saúde Educ 2010; 14:217-27.

14. Jucá NBH, Gomes AMA, Mendes LS, Gomes DM, Martins BVL, Silva CMGC, et al. A comunicação do diagnóstico "sombrio" na relação médico-paciente entre estudantes de Medicina: uma experiência de dramatização na educação médica. Rev Bras Educ Méd 2010; 34:57-64.

15. Stelet BP, Castiel LD, Moraes DR. Anomalisa e o ensino da comunicação clínica na prática médica. Cad Saúde Pública 2017; 33:e00154016.

16. Makoul G. The SEGUE Framework for teaching and assessing communication skills. Patient Educ Couns 2001; 45:23-34.

17 Zill JM, Christalle E, Müller E, Härter M, Dirmaier J, Scholl I. Measurement of physicianpatient communication: a systematic review. PLoS One 2014; 9:e112637.

18. Kurtz SM, Silverman JD. The Calgary-Cambridge Referenced Observation Guides: an aid to defining the curriculum and organizing the teaching in communication training programmes. Med Educ 1996; 30:83-9.

19. Krupat E, Frankel R, Stein T, Irish J. The Four Habits Coding Scheme: validation of an instrument to assess clinicians' communication behavior. Patient Educ Couns 2006; 62:38-45.

20. Scholl I, Nicolai J, Pahlke S, Kriston L, Krupat E, Härter M. The German version of the Four Habits Coding Scheme - association between physicians' communication and shared decision making skills in the medical encounter. Patient Educ Couns 2014; 94:224-9.

21. Wild D, Grove A, Martin M, Eremenco S, McElroy S, Verjee-Lorenz A, et al. Principles of good practice for the translation and cultural adaptation process for patient-reported outcomes (PRO) measures: report of the ISPOR Task Force for Translation and Cultural Adaptation. Value Health 2005; 8:94-104.

22. Eremenco SL, Cella D, Arnold BJ. A comprehensive method for the translation and crosscultural validation of health status questionnaires. Eval Health Prof 2005; 28:212-32.

23. Hasson F, Keeney S, McKenna H. Research guidelines for the Delphi survey technique. J Adv Nurs 2000; 32:1008-15.

24. Hsu C-C, Sandford B. The Delphi technique: making sense of consensus. Practical Assessment, Research \& Evaluation 2007; 12:1-8.
25. Willis GB. Cognitive interviewing: a tool for improving questionnaire design. Thousand Oaks: Sage Publications; 2005.

26. Ruperto N, Ravelli A, Pistorio A, Malattia C, Cavuto S, Gado-West L, et al. Cross-cultural adaptation and psychometric evaluation of the Childhood Health Assessment Questionnaire (CHAQ) and the Child Health Questionnaire (CHQ) in 32 countries. Review of the general methodology. Clin Exp Rheumatol 2001; 19(4 Suppl 23):S1-9.

27. Ruben R, Oliveira ACD, Savassi LCM, Souza LC, Dias RB. Abordagem centrada nas pessoas. Rev Bras Med Fam Comunidade 2009; 4:24559.

28. Núcleo Técnico da Política Nacional de Humanização, Secretaria-Executiva, Ministério da Saúde. HumanizaSUS - Política Nacional de Humanização. A humanização como eixo norteador das práticas de atenção e gestão em todas as instâncias do SUS. Brasília: Ministério da Saúde; 2004

29. Ministério da Saúde. Cadernos HumanizaSUS. Brasília: Ministério da Saúde; 2012. (Série B: Textos Básicos de Saúde).

30. Szasz TS, Hollender MH. A contribution to the philosophy of medicine: the basic models of the doctor-patient relationship. AMA Arch Intern Med 1956; 97:585-92.

31. Kaba R, Sooriakumaran P. The evolution of the doctor-patient relationship. Int J Surg 2007; 5:57-65.

32. Dwamena F, Holmes-Rovner M, Gaulden CM, Jorgenson S, Sadigh G, Sikorskii A, et al. Interventions for providers to promote a patient-centred approach in clinical consultations. Cochrane Database Syst Rev 2012; (12):CD003267.

33. Lewin SA, Skea ZC, Entwistle V, Zwarenstein $\mathrm{M}$, Dick J. Interventions for providers to promote a patient-centred approach in clinical consultations. Cochrane Database Syst Rev 2001;(4):CD003267.

34. Pilnick A, Dingwall R. On the remarkable persistence of asymmetry in doctor/patient interaction: a critical review. Soc Sci Med 2011; 72:1374-82.

35. Boden D, Zimmerman DH, editors. Talk and social structure: studies in ethnomethodology and conversation analysis. Berkeley: University of California Press; 1991.

36. Nelson WA, Forcino RC, Elwyn G. Patientcentered organizational statements: merely rhetoric? A survey of health care leaders. Health Care Manag (Frederick) 2017; 36:342-6.

37. Gjersing L, Caplehorn JR, Clausen T. Crosscultural adaptation of research instruments: language, setting, time and statistical considerations. BMC Med Res Methodol 2010; 10:13.

38. Reichenheim ME, Moraes CL. Operationalizing the cross-cultural adaptation of epidemiological measurement instruments. Rev Saúde Pública 2007; 41:665-73. 


\section{Resumo}

As diretrizes brasileiras para a educação enfatizam as habilidades de comunicação centradas no paciente enquanto importante competência para os estudantes de medicina. O Four Habits Coding Scheme (4HCS) é um instrumento utilizado no ensino e avaliação das habilidades de comunicação do clínico em uma abordagem de cuidado centrado na pessoa. O nosso objetivo foi traduzir e realizar a adaptação transcultural do 4HCS para o português do Brasil. O processo de tradução foi realizado em sete estágios: tradução independente, reconciliação, retro-tradução, revisão pelo autor, revisão independente - consenso através da técnica Delphi -, revisão por um coordenador linguístico e pré-teste. Durante o préteste, três observadores independentes avaliaram quatro consultas médicas realizadas por estudantes e residentes de medicina que foram gravadas em um cenário de atendimento real. Os revisores tiveram dificuldade em chegar a um consenso sobre expressões referentes à compreensão da pessoa como um todo, tais como "engage in small talk", "expansion of concerns", "elicit full agenda", "use patient's frame of reference" $e$ "explore plan acceptability”. Também tiveram dificuldade em chegar a um consenso sobre a tradução da palavra "clinician", que fora traduzida primeiro como "médico". Questões históricas e culturais na relação médico-paciente podem ter influenciado o resultado. A versão brasileira do 4 HCS é um instrumento válido no sentido cultural, conceitual, semântico e operacional. Pode representar um avanço importante no fortalecimento do modelo de cuidado centrado no paciente no Brasil.

Assistência Centrada no Paciente; Comunicação em Saúde; Educação Médica; Avaliação Educacional; Comparação Transcultural

\section{Resumen}

Las directrices brasileñas para la educación enfatizan las habilidades de comunicación centradas al paciente, por considerarla una importante competencia para los estudiantes de medicina. El Four Habits Coding Scheme (4HCS) es un instrumento utilizado en la enseñanza y evaluación de las habilidades de comunicación dentro del ámbito clínico, desde una perspectiva de cuidado centrado en la persona. El objetivo fue traducir y realizar la adaptación transcultural del 4HCS al portugués de Brasil. El proceso de traducción se realizó en siete fases: traducción independiente, conciliación, retro-traducción, revisión por parte del autor, revisión independiente -consenso a través de la técnica Delphi-, revisión por parte de un coordinador lingüístico y prueba previa. Durante la prueba previa, tres observadores independientes evaluaron cuatro consultas médicas, que fueron realizadas por estudiantes y residentes de medicina que se grabaron en un escenario de atención real. Los revisores tuvieron dificultades para llegar a un consenso sobre expresiones referidas a la comprensión de la persona como un todo, tales como "engage in small talk", "expansion of concerns", "elicit full agenda", "use patient's frame of reference" $y$ "explore plan acceptability". También tuvieron dificultades para llegar a un consenso sobre la traducción de la palabra "clinician", que se tradujo en primera instancia como "médico". Las cuestiones históricas y culturales en la relación médico-paciente pueden haber influenciado el resultado. La versión brasileña del 4 HCS es un instrumento válido, en el sentido cultural, conceptual, semántico y operacional. Puede representar un avance importante en el fortalecimiento del modelo de cuidado centrado en el paciente en Brasil.

Atención Dirigida al Paciente; Comunicación en Salud; Educación Médica; Evaluación

Educacional; Comparación Transcultural

Submitted on 24/Jan/2018

Final version resubmitted on $07 / \mathrm{Jul} / 2018$

Approved on 03/Aug/2018 